\title{
On the Wave Energy Assessment in the South China Sea
}

\author{
Osinowo Adekunle Ayodotun ${ }^{1, *}$, Xiaopei Lin ${ }^{1}$, Zhao Dongliang ${ }^{1}$ and Wang Zhifeng ${ }^{2}$ \\ ${ }^{1}$ College of Physical and Environmental Oceanography, Ocean University of China, Qingdao, 266100, China \\ ${ }^{2}$ College of Engineering, Ocean University of China, Qingdao, 266100, China
}

\begin{abstract}
This paper presents a thirty year (1976-2005) assessment of wave energy resource within the South China Sea (SCS) by simulation. Significant wave height (SWH) between simulation and observation shows good agreement. This shows the reliability of an along-side simulated wave period in estimating wave energy in the SCS. Results show that estimates of wave power density are more reliable in the north-central SCS and most sufficient during winter. The annual mean wave power density peaked at $12.7 \mathrm{~kW} / \mathrm{m}$ and $12.9 \mathrm{~kW} / \mathrm{m}$ during years 1986 and 1999 respectively while the highest seasonal mean of $29 \mathrm{~kW} / \mathrm{m}$ occurred in year 1999 during winter. The wave power density is most stable in winter and is generally more stable in offshore regions of SCS. Wave power density is most stable in years 1976, 1997 and 2004 with stability values of 1.96, 1.98 and 1.9 respectively. The stability value of 0.9 in year 1980 is the greatest in the winter of all years. Relative-rich energy regions occupy the largest area during winter. The relatively richest energy is generally concentrated in the central and north-central SCS. No area is identified as a relative-rich energy region during spring. Winter 1999 has the highest relative-rich energy with value of $37 \mathrm{~kW} / \mathrm{m}$.
\end{abstract}

Keywords: South China Sea, Wave power density, Wave power stability, Relative-rich energy, Distribution.

\section{INTRODUCTION}

The South China Sea (SCS) is remarkably the deepest and largest sea around China with an average water depth of $1212 \mathrm{~m}$ and a maximum depth of 5567 m (Figure 1).

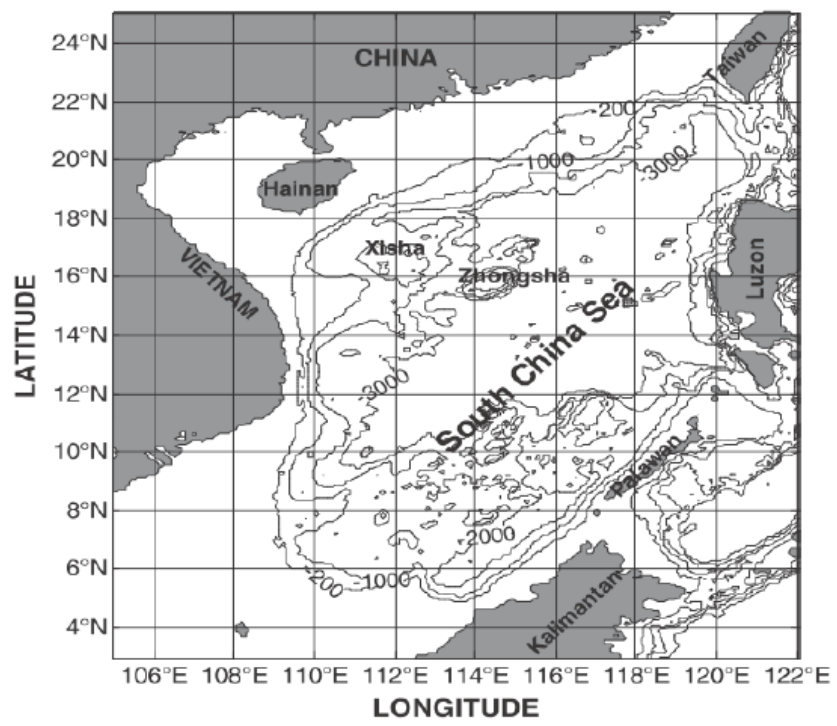

Figure 1: Geography and Bathymetry of the SCS.

After the Coral Sea and Arabian Sea, it is the third largest epi-continental sea in the global oceans. The SCS is a half-enclosed tropical sea within complex topography between the Asian landmass to the north and west, the Philippine Islands to the east, Borneo to the southeast, and Indonesia to the south [1]. The

*Address correspondence to this author at the College of Physical and Environmental Oceanography, Ocean University of China, Qingdao, 266100, China; Tel: 86 13791807391; E-mail: voxfox99@yahoo.com water volume is 3.5-3.85 million cubic square meters, which is about 13 times that of the total volume of the East China Sea, the Yellow Sea, and the Bohai Sea. The SCS is under the influence of monsoon winds and synoptic systems such as fronts and tropical cyclones [2-4].

The ocean energy has advantages of clean, renewable, huge reserves, and wide distribution; however, its instability increases the difficulty for development [5]. In order to improve the capture ability, previous researchers have made great contribution to the upgrade of the wave power equipment $[6,7]$.

$[8,9]$ have analyzed the offshore and inshore wave energy resource in Asturias (IN Spain), using wave buoy data and a 44-yr hind cast wave data obtained with Simulating WAves Nearshore (SWAN) wave model. Results show that the offshore average wave power and annual wave energy values exceed 30 $\mathrm{kW} / \mathrm{m}$ and $250 \mathrm{MW} \mathrm{h} / \mathrm{m}$. Most of the energy is provided by IV quadrant waves with significant wave heights between $2 \mathrm{~m}$ and $5 \mathrm{~m}$ and energy periods between $11 \mathrm{~s}$ and $13 \mathrm{~s}$.

The evaluation of the wave power site selection is also a function of the stability of wave power density. More stability more better acquisition and conversion of wave energy. The instability of the wave energy density will reduce the conversion efficiency of the ocean energy conversion transpose, and even more, damage the power equipment [10].

In China, the wave energy resource evaluation is mostly based on very limited buoy material or shipping data $[11,12]$. 
With the urbanization at the Beibu Gulf Economic Zone, located at the northwest of the South China Sea, many new industries are imported, accompanying a large amount of immigration. As a result, Beibu Gulf Economic Zone is facing a shortage of electricity. The local government urgently requires developing wave energy to ease the pressure of power shortage. Although the early investigations for estimation of the wave energy resources in the Beibu Gulf have been conducted, such as [13-16], their investigations have the shortcomings that they investigate the local wave energy resources at a large scale, such as a global scale or a national scale, which lead to the misestimation of wave energy due to the low temporal spatial resolution of the wave energy in the Beibu Gulf and that the quantitative analysis of wave energy has not been provided, especially the fact that the wave energy per unit has not been discussed in detail. In addition, the direction and the cycle of the wave energy variation have not been conducted.

The richness of wave energy resources is an important factor in identifying ideal locations for wave power plants $[15,17,18]$ indicated that wave energy is available when wave power is greater or equal to $2 \mathrm{~kW} / \mathrm{m}$ and is rich when wave power is greater or equal to $20 \mathrm{~kW} / \mathrm{m}$.

This study aims to investigate the spatio-temporal characteristic and stability of the wave power density and also the seasonal distribution of relative rich energy regions of wave power density in the SCS.

\section{METHODOLOGY AND DATA}

\subsection{The SCS Ocean Wave Model and Wind Data}

In this study, the wave climate over 272 locations in the SCS was hindcasted with version 3.14 of the thirdgeneration spectral wave model WAVEWATCH III ${ }^{\mathrm{TM}}$ (denoted as WW3) [19]. The model spatial grid covers the whole of SCS and part of ECS from longitudes $95^{\circ} \mathrm{E}$ to $135^{\circ} \mathrm{E}$ and latitudes $5^{\circ} \mathrm{S}$ to $30^{\circ} \mathrm{N}$ with a $0.25^{\circ}$ resolution. The model was forced with 6hour reanalysis wind fields extracted over longitudes $95^{\circ} \mathrm{Eto}$ $135^{\circ} \mathrm{E}$ and latitudes $5^{\circ} \mathrm{S}$ to $30^{\circ} \mathrm{N}$ from the WRF model available from 1976 to 2005 on a $0.2^{\circ}$ (longitude) by $0.2^{0}$ (latitude) Gaussian grid. Wind fields were interpolated on a regular $0.25^{\circ}$ grid to force the model.

A 30-year simulation was performed from 1976 to 2005 and provided a 6hour time series of SWH and other wave parameters over a box extending from $3^{0} \mathrm{~N}$ to $23^{\circ} \mathrm{N}$ and $105^{\circ} \mathrm{E}$ to $121^{\circ} \mathrm{E}$ which corresponds to the SCS mentioned above.

\subsection{Data Validation}

The TOPEX/Poseidon data was used to verify the accuracy of the WW3 simulations. The TOPEX/Poseidon satellite crossover points in the SCS from January 1 to December 31, 2002 are shown in Figure 2.

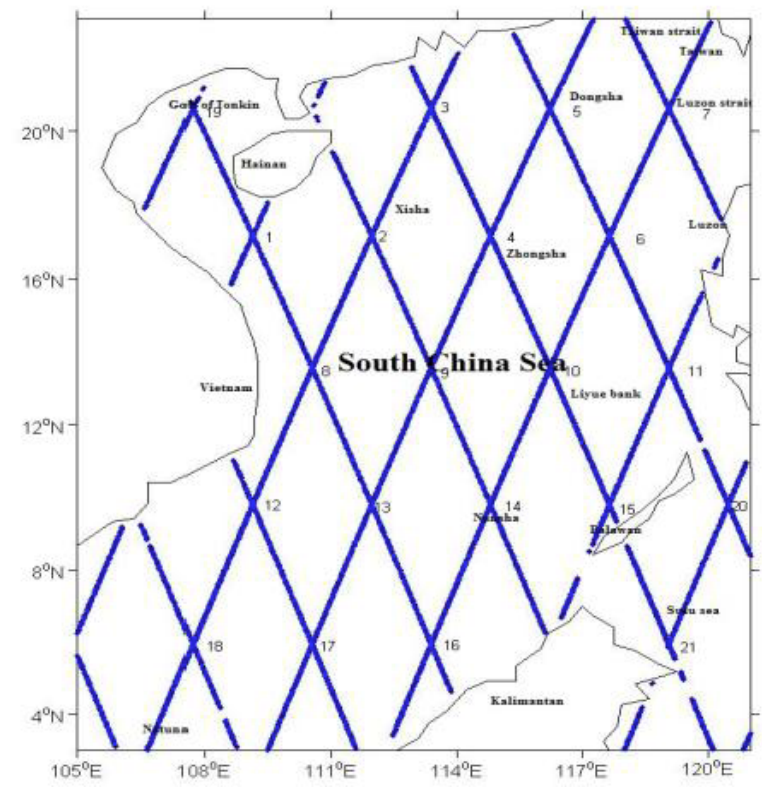

Figure 2: Topex/Poseidon crossover points and Geography of the SCS.

The model SWH data were interpolated into all the crossover points where the hindcast and altimeter data were computed. Comparisons were conducted between the model hindcast results and the Topex/Poseidon altimeter observations. Synchronous comparisons of SWH are shown in Figures $\mathbf{3 a}$ and $\mathbf{3 b}$. The time series cover different periods in year 2002 for all the crossover points as Topex/Poseidon passed over the SCS.

The skill of the model was evaluated through a statistical study that consists on calculating the following:

$$
\begin{aligned}
& c c=\frac{\sum_{i-1}^{n}\left(x_{i}-\bar{x}\right)\left(y_{i}-\bar{y}\right)}{\sqrt{\sum_{i-1}^{n}\left(x_{i}-\bar{x}\right)^{2} \sum_{i-1}^{n}\left(y_{i}-\bar{y}\right)^{2}}} \\
& \text { Bias }=\bar{y}-\bar{x} \\
& \text { RMSE }=\sqrt{\frac{1}{N} \sum_{i-1}^{n}\left(y_{i}-x_{i}\right)^{2}}
\end{aligned}
$$



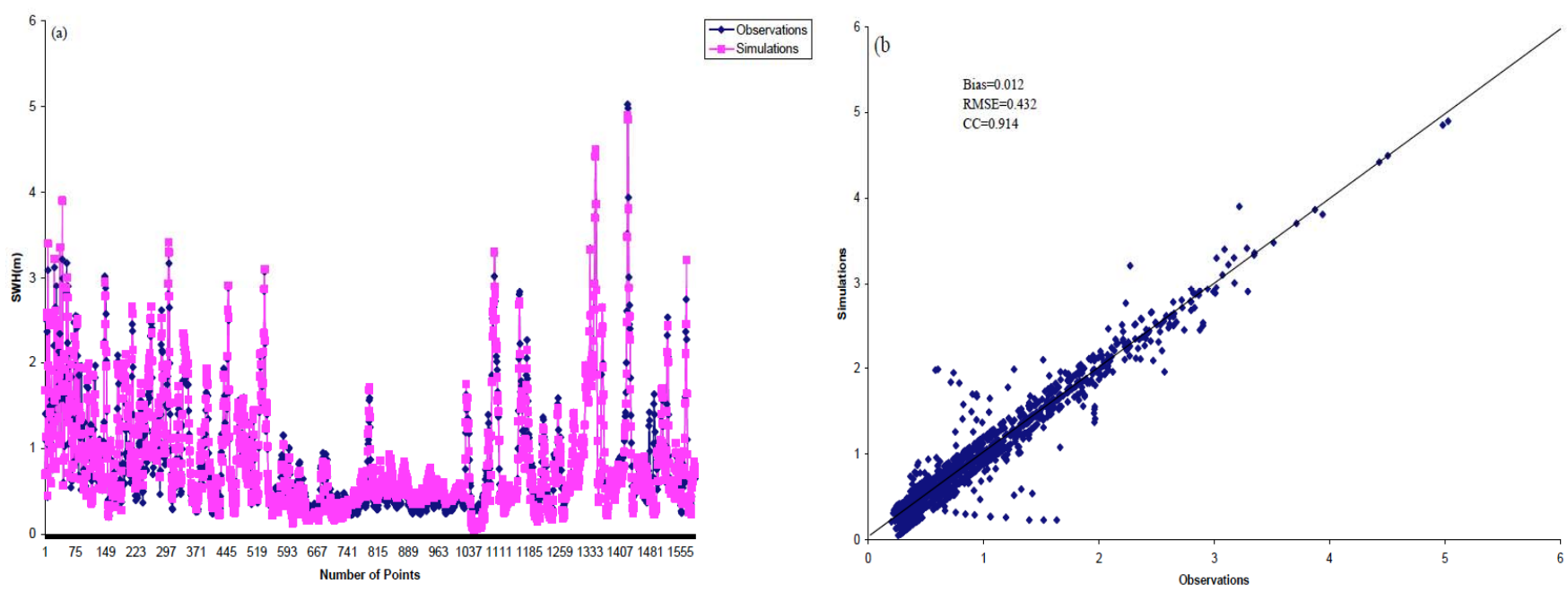

From 01-Jan-2002 to 31-Dec-2002

Figure 3: (a) Time series of the wave model data against Topex/Poseidon data for the SWH, on the $\mathrm{x}$-axis is the number of data points. (b) Scatter plot of the wave model data against Topex/Poseidon data for the SWH.

$S I=\frac{R M S E}{\bar{x}}$

where, xi represents the observed data, $y_{i}$ represents the simulated data, $x$ and $y$ are mean value of observed and simulated data, $\mathrm{N}$ is the total number of observations. The correlation coefficient (cc) between the simulated and observed data is 0.914 which indicates a close relationship between simulated and observed data. From Bias which is $0.012 \mathrm{~m}$, we find that the model slightly overestimates the observed SWH. The RMSE between the simulated and observed data is $0.432 \mathrm{~m}$ indicating a low error of simulated data while the scatter index is 0.162 . In general, the simulation results are consistent with the observations, which indicate that in general the WW3 can well reproduce the SWH and as well be a dependable model to simulate surface waves in the SCS.

\subsection{Wave Power Density Evaluation}

By using a 30 year (Jan 1, 1976 to December 31, 2005) hindcast data of the SWH and wave period, a 6 hour SCS wave power density was obtained using the evaluation method of [20-22]. The evaluation method is as follows:

$P_{w}=\frac{\rho g^{2}}{64 \Pi} H_{m o}^{2} T_{e}=0.49 H_{m o}^{2} T_{e}$

where $P_{\mathrm{w}}$ is wave power (unit: $\mathrm{kW} / \mathrm{m}$ ), $H_{\mathrm{mo}}$ is the significant wave height (unit: $\mathrm{m}$ ), and $T_{\mathrm{e}}$ is the energy period (unit: s).

\subsubsection{Annual and Seasonal Characteristics of the Wave Power Density}

\subsubsection{Regional Variation}

The distribution of annual and seasonal mean wave power density derived from analysis of the WW3-SCS wave climatology are presented in Figures $\mathbf{4}$ and $\mathbf{5}$. From Figure 4, the annual mean wave power density is greatest $(14-20 \mathrm{~kW} / \mathrm{m})$ in the central SCS and in some regions in the north-central SCS particularly around Xisha and Zhongsha with wave power density greater than $20 \mathrm{~kW} / \mathrm{m}$. Lower values $(<10 \mathrm{~kW} / \mathrm{m})$ dominate most parts of the southern SCS. Smallest values $(<2 \mathrm{~kW} / \mathrm{m})$ are particularly found around northwest of Hainan, Vietnam borders, Kalimantan and Palawan.

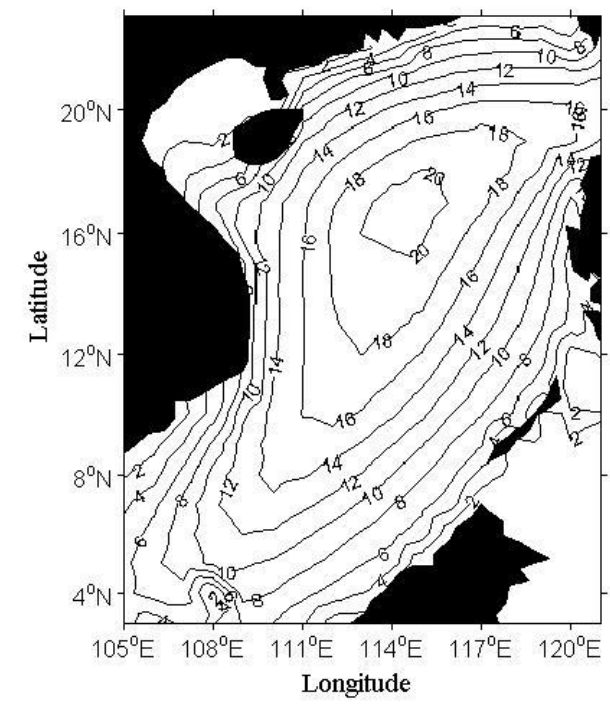

Figure 4: Annual mean wave power density in the SCS, unit: $\mathrm{kW} / \mathrm{m}$. 

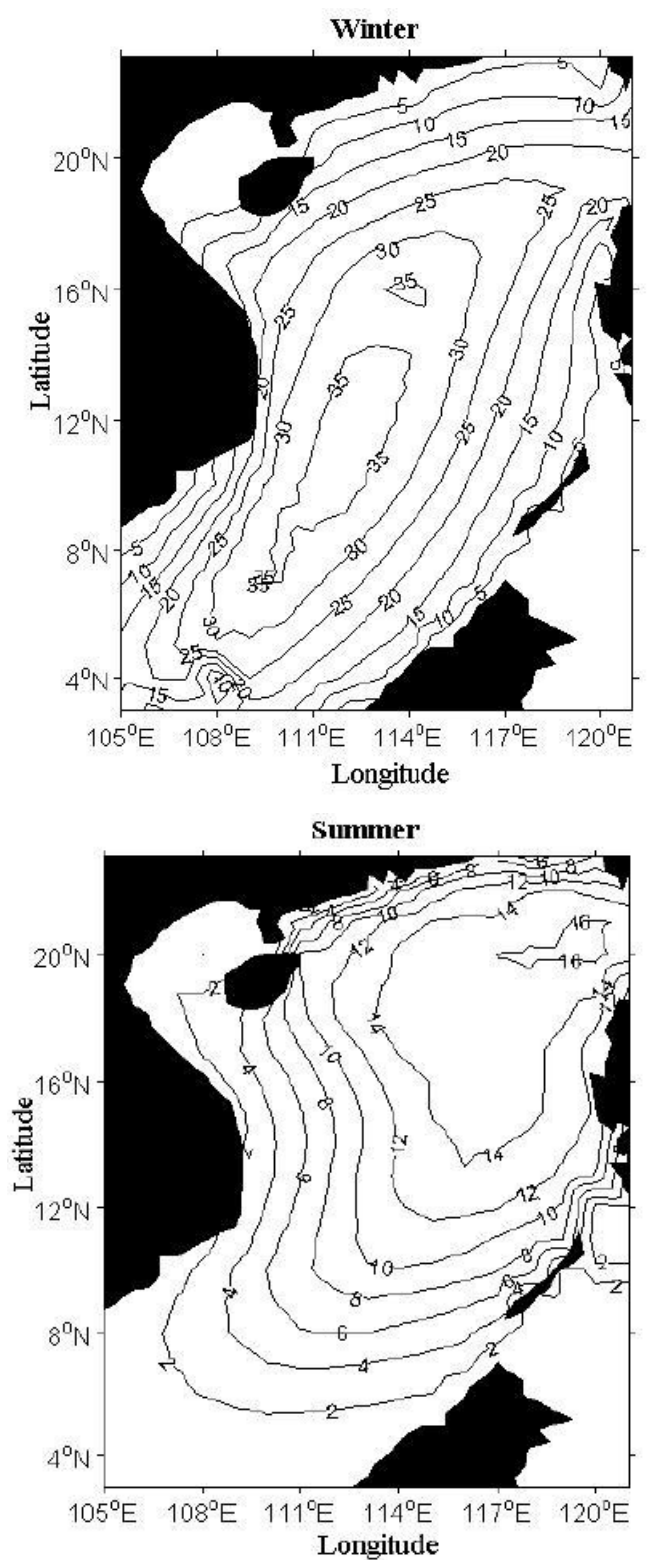
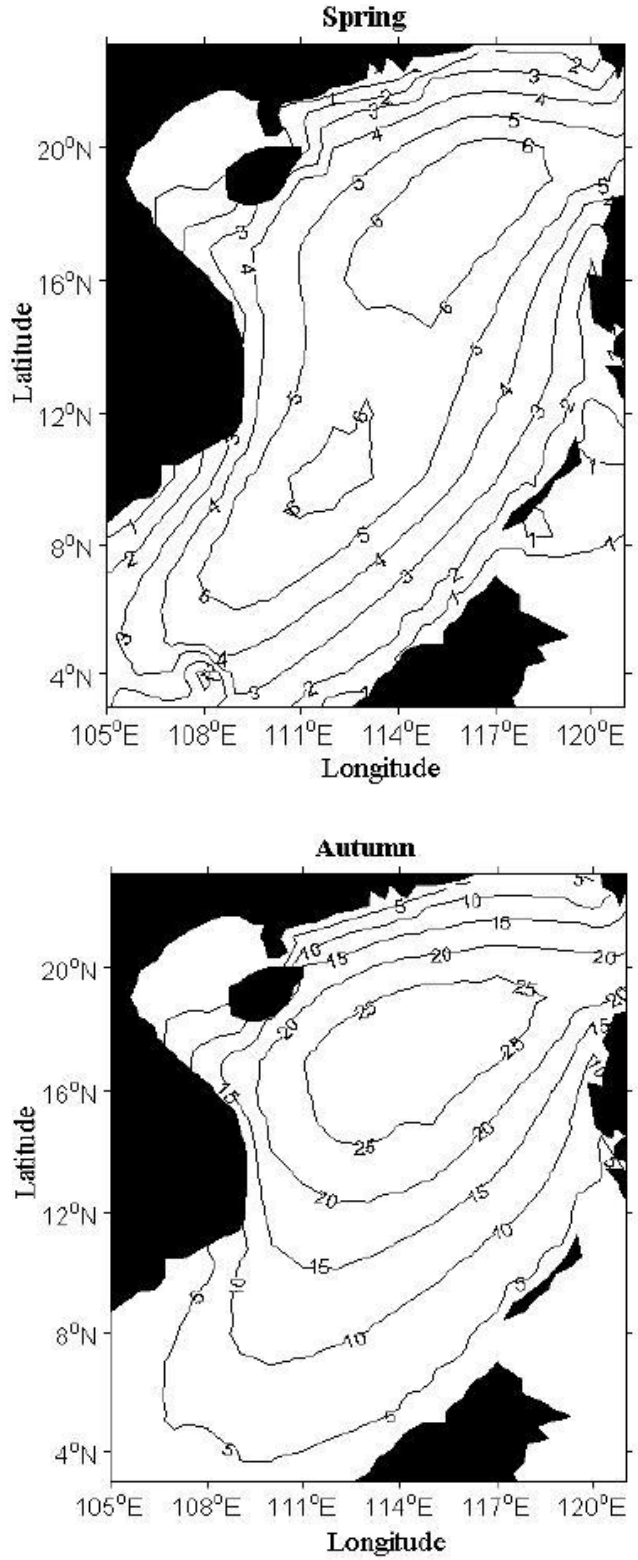

Figure 5: Seasonal mean wave power density in the SCS, unit: kW/m.

As can be seen in Figure 5, during winter, greatest values of the wave power density $(30-40 \mathrm{~kW} / \mathrm{m})$ are concentrated in the central SCS. Least values $(<5 \mathrm{~kW} / \mathrm{m})$ distribute round Hainan, Kalimantan and Palawan. In spring, largest values of the wave power density $(6-8 \mathrm{~kW} / \mathrm{m})$ concentrate around Xisha and Zhongsha. Lower values $(5-6 \mathrm{~kW} / \mathrm{m})$ are found in the central SCS. Extremely low values $(<1 \mathrm{~kW} / \mathrm{m})$ are seen around Hainan, Kalimantan and Palawan. During summer, large area with high wave power density values $(13-17 \mathrm{~kW} / \mathrm{m})$ are located within Xisha, Zhongsha, and west of the Luzon and close to Taiwan Island. Wave power density values less than $4 \mathrm{~kW} / \mathrm{m}$ dominate most part of the southern SCS and around Hainan. During autumn, wave power density (25-
$30 \mathrm{~kW} / \mathrm{m}$ ) is largest around Xisha and Zhongsha. Least values $(<5 \mathrm{~kW} / \mathrm{m})$ are found around Hainan, Kalimantan, Palawan and southwest corner of the southern SCS. Wave power density is generally largest in winter in the whole year; of above $9 \mathrm{~kW} / \mathrm{m}$ in most part of the SCS, it is greater than $6 \mathrm{~kW} / \mathrm{m}$ in most regions of the SCS in autumn and below $8 \mathrm{~kW} / \mathrm{m}$ in most regions of the SCS in spring. These results are consistent with the findings of [23].

\subsubsection{Inter-Annual Variation}

The temporal variations of the annual and seasonal mean wave power density in the SCS are presented in Figures 6 and 7 . From Figure $\mathbf{6}$, highest wave power density values $(12.7 \mathrm{~kW} / \mathrm{m}$ and $12.9 \mathrm{~kW} / \mathrm{m})$ are found in 


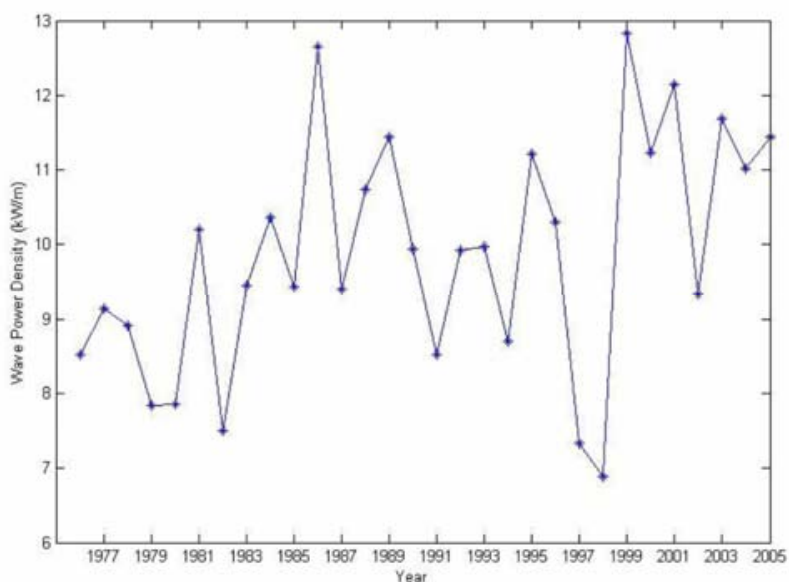

Figure 6: Variation of the annual mean wave power density, unit: $\mathrm{kW} / \mathrm{m}$.

years 1986 and 1999 while smallest values $(7.5 \mathrm{~kW} / \mathrm{m}$, $7.3 \mathrm{~kW} / \mathrm{m}$ and $6.8 \mathrm{~kW} / \mathrm{m}$ ) are respectively seen in years
1982, 1997 and 1998. From Figure 7, during winter, largest wave power density of $29 \mathrm{~kW} / \mathrm{m}$ is found in the year 1999. Least values $(10.3 \mathrm{~kW} / \mathrm{m}, 13 \mathrm{~kW} / \mathrm{m}$, $12.5 \mathrm{~kW} / \mathrm{m}$ and $12.1 \mathrm{~kW} / \mathrm{m}$ ) are respectively noticed in years 1979, 1982, 1992 and 1994. During spring, highest wave power density values of $6.5 \mathrm{~kW} / \mathrm{m}, 6 \mathrm{~kW} / \mathrm{m}$ and $6.7 \mathrm{~kW} / \mathrm{m}$ are respectively found in years 1986 , 1989 and 2005 . Smallest values of $1.7 \mathrm{~kW} / \mathrm{m}, 1.6 \mathrm{~kW} / \mathrm{m}$ and $1.4 \mathrm{~kW} / \mathrm{m}$ are respectively noted in years 1979 , 1983 and 1992. In summer, the wave power density peaks at $12.2 \mathrm{~kW} / \mathrm{m}$ in year 2002 while the least value of $1 \mathrm{~kW} / \mathrm{m}$ is seen in year 1998. During autumn, the wave power density peaks at $16.5 \mathrm{~kW} / \mathrm{m}, 16.9 \mathrm{~kW} / \mathrm{m}$, $17.2 \mathrm{~kW} / \mathrm{m}$ and $17.4 \mathrm{~kW} / \mathrm{m}$ respectively in years 1983 , 1986, 1988 and 1992. Minimum values of $7.2 \mathrm{~kW} / \mathrm{m}$, $7 \mathrm{~kW} / \mathrm{m}, 6.7 \mathrm{~kW} / \mathrm{m}$ and $5.8 \mathrm{~kW} / \mathrm{m}$ are respectively noted in years 1980, 1982, 1987 and 1997.
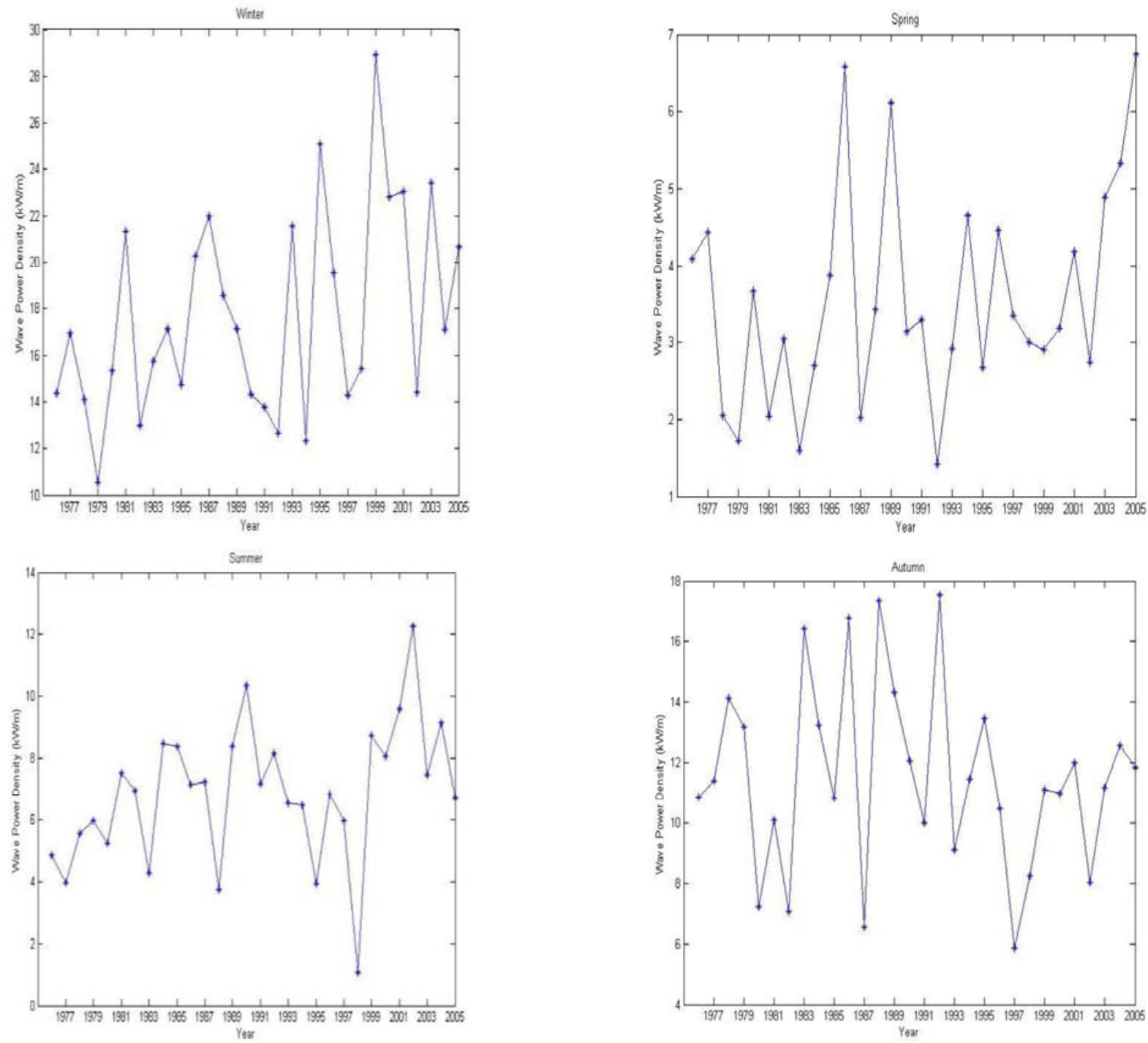

Figure 7: Variation of the seasonal mean wave power density, unit: $\mathrm{kW} / \mathrm{m}$. 


\subsection{Stability of the Wave Power Density}

Many measures can be conceived to describe the temporal variability in wave power at a site. One simple, straightforward measure is the coefficient of variation (cov). The wave power density stability is evaluated by calculating the cov for each grid point. The lesser the cov, the more the stability.

The cov calculating formula is as follows:

$\operatorname{cov}=\frac{s}{x}$

Where $s$ is the standard deviation and is evaluated as:

$S=\sqrt{\frac{\sum_{i=1}^{n} x_{i}^{2}-\left(\sum_{i=1}^{n} x_{i}\right)^{2} / n}{n-1}}$

$\bar{x}$ is the mean value.

\subsubsection{Annual and Seasonal Stability of the Wave Power Density}

\subsubsection{Regional Variation}

Figures 8 and 9 show the distribution of the annual and seasonal mean wave power density stability in the SCS. It can be seen from Figure 8 that the wave power density stability decreases upwards (cov 1-5) in most waters from the southern to the northern SCS. It is least stable (cov 5.2-12) in a small region directly north of Hainan.

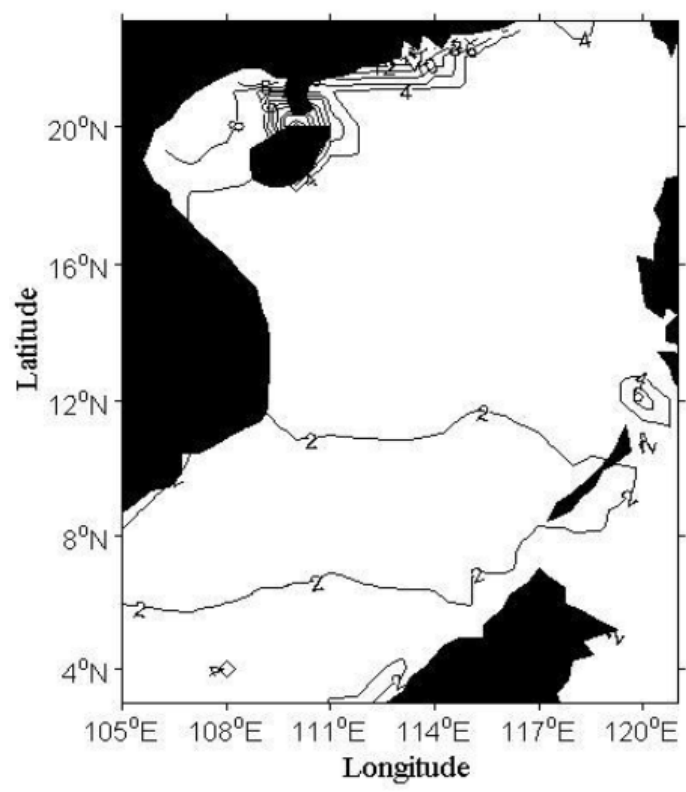

Figure 8: Annual mean wave power density stability in the SCS.
From Figure 9, the stability of wave power density exhibits obvious regional and seasonal differences. The seasonal difference resulted from the influence of the monsoon. During the winter, the wave power density stability is high in most regions of the SCS. Lower stability (cov>1.4) is found around Hainan, Kalimantan, Palawan and waters west of the Luzon. The instability of wave power density is most pronounced few waters in the northern and southern SCS. During the spring, high stability $(\operatorname{cov}<2)$ is noticed around northwest axis of Hainan, borders of Vietnam and in some regions of central SCS. The wave power density is less stable in most regions of the northern and southern SCS with cov between 2 and 2.7. The stability is smallest (cov>2.7) in small regions northeast of Hainan and in the southern SCS. During summer, the wave power density is more stable $(\operatorname{cov}<2.5)$ in the central and southern SCS than in the northern SCS. The wave power density is particularly less stable (cov 3-7) around Hainan. During autumn, the wave power density is more stable $(\operatorname{cov}<2)$ in the southern SCS than in the central and northern SCS. The degree of instability of wave power density (cov 2.7-5.5) is largest around Hainan and waters to its northeast and northwest axis. In general, the wave power density is most stable in the winter because the ocean waves caused by frequent cold airs are often relatively regular and stable. Also, wave power density in the offshore is more stable than in the near shore regions of the SCS.

\subsubsection{Inter-annual variation}

Figures 10 and $\mathbf{1 1}$ display the temporal variation of the annual and seasonal average wave power density stability in the SCS. It is seen from Figure $\mathbf{1 0}$ that the wave power density is most stable in the years 1976, 1997 and 2004 with stability values of 1.96, 1.98 and 1.9. The year of least stability is in 1998 with stability of 2.96 .

From Figure 11, during the winter, the wave power density is most stable in year 1980 with cov of 0.9 and least stable in 1998 with cov of 2.0. During spring, the wave power density has the highest stability in years 1992 and 1998 with cov of 1.3 and 1.41 respectively while years 1977, 1989 and 2004 have the poorest stability with stability values of $2.8,2.7$ and 3.1 respectively. During summer, years 1994 and 2004 are years of greatest stability in the wave power density with stability values of 1.5 and 1.47 respectively whereas least stability can be seen in years 1980 and 1992 with cov of 2.57 and 2.56 respectively. During autumn, the greatest stability in the wave power density 

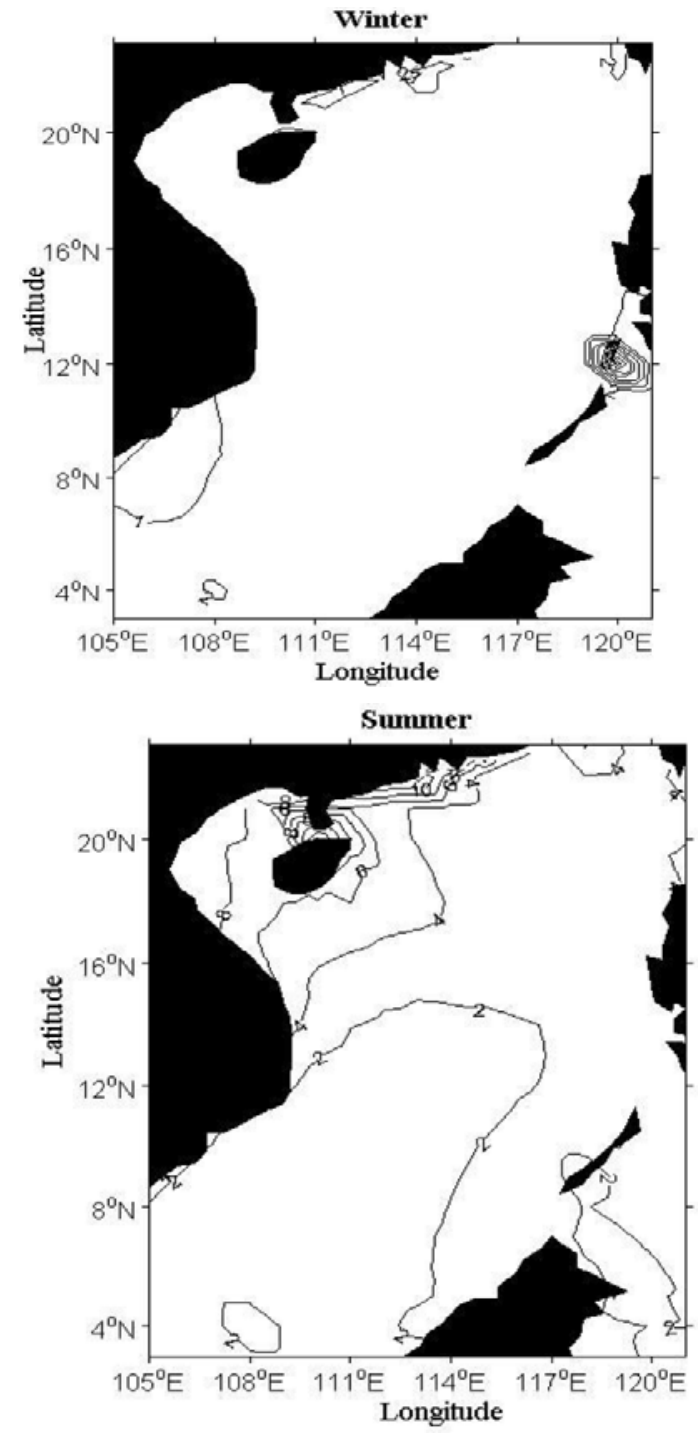
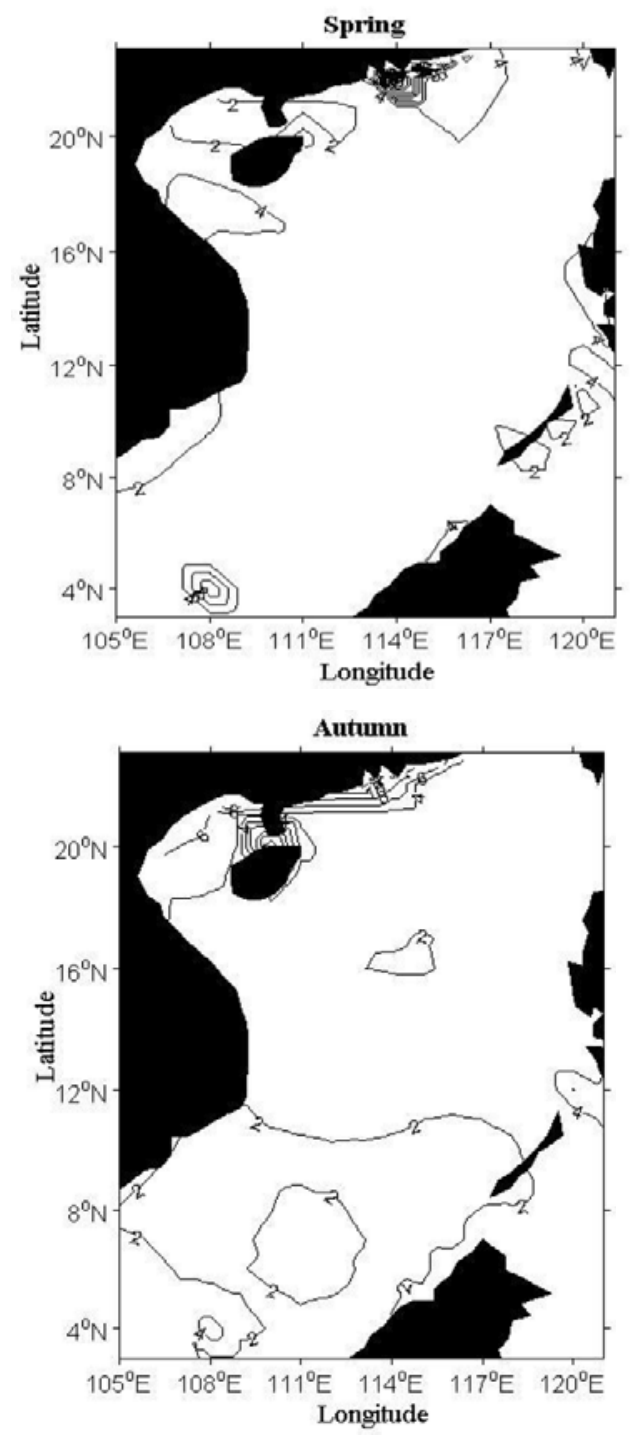

Figure 9: Seasonal mean wave power density stability in the SCS.

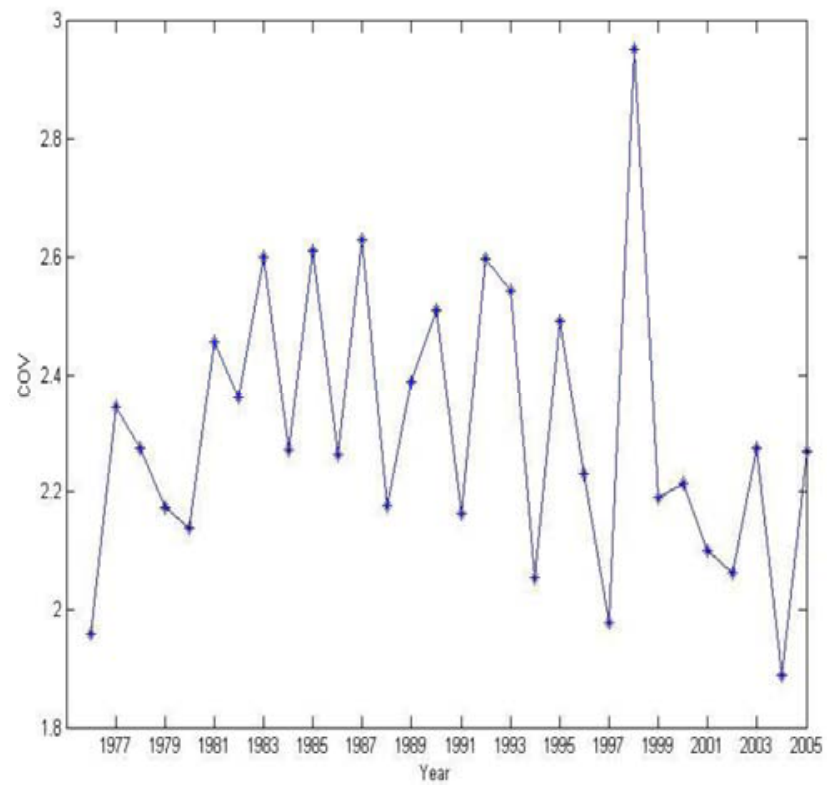

Figure 10: Variation of the annual mean wave power density stability. 

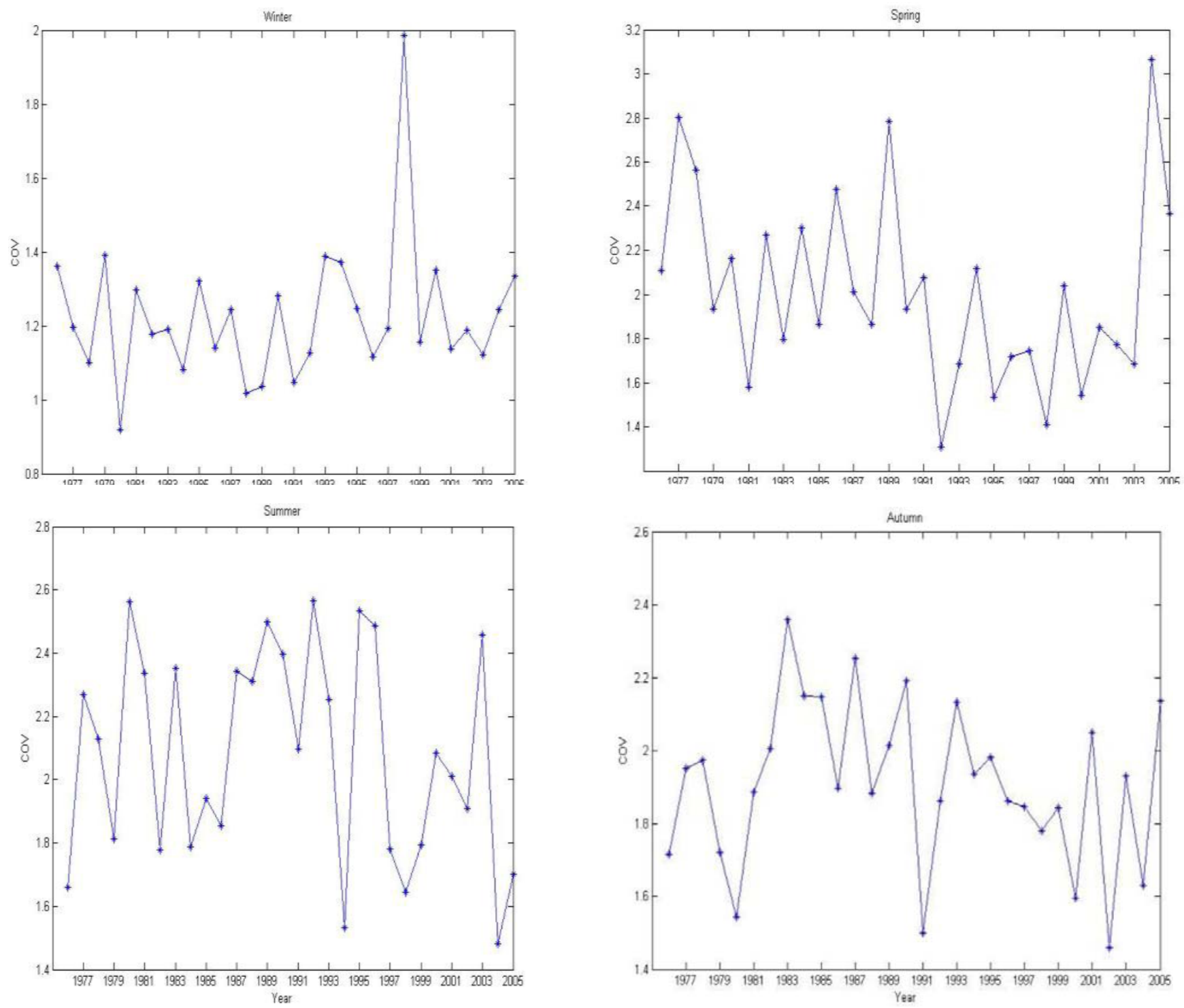

Figure 11: Variation of the seasonal mean wave power density stability.

is found in years 1980,1991 and 2002 with cov of 1.5, 1.49 and 1.42 respectively. The wave power density is least stable in year 1983 with cov of 2.35 .

\subsection{Relative Rich-Energy Region of the Wave Power Density}

The distribution of relative rich-energy region changes along with season from the value and stability of the wave power density [23]. Suppose the region with seasonal average wave power density above $6 \mathrm{~kW} / \mathrm{m}$ and the cov is below 2.0 as the relative richenergy region. This is adopted in this study.

\subsubsection{Regional Variation}

\subsubsection{Inter-annual variation}

The seasonal and temporal distribution of the relative-rich energy regions of wave power density are shown in Figures 12 and 13. As seen in Figure 12, during winter, relative-rich energy area distribute round most part of the SCS. Relative-rich energy is most intense in the central SCS and around Xisha and Zhongsha with wave power density between $30 \mathrm{~kW} / \mathrm{m}$ and $40 \mathrm{~kW} / \mathrm{m}$. Hainan, Kalimantan and Palawan are regions of no relative-rich energy. During spring, all areas of the SCS do not contain relative-rich wave power density. Ordinary wave energy is only available. Area of relative-rich energy distribute primarily in the central SCS during summer. The wave power density relative-rich energy region occupies a larger area in autumn than in summer. The area of relative-rich energy distribute primarily in the central SCS and around Xisha and Zhongsha.

From Figure 13, during the winter, the wave power density relative-rich energy peaks at $37 \mathrm{~kW} / \mathrm{m}$ in year 

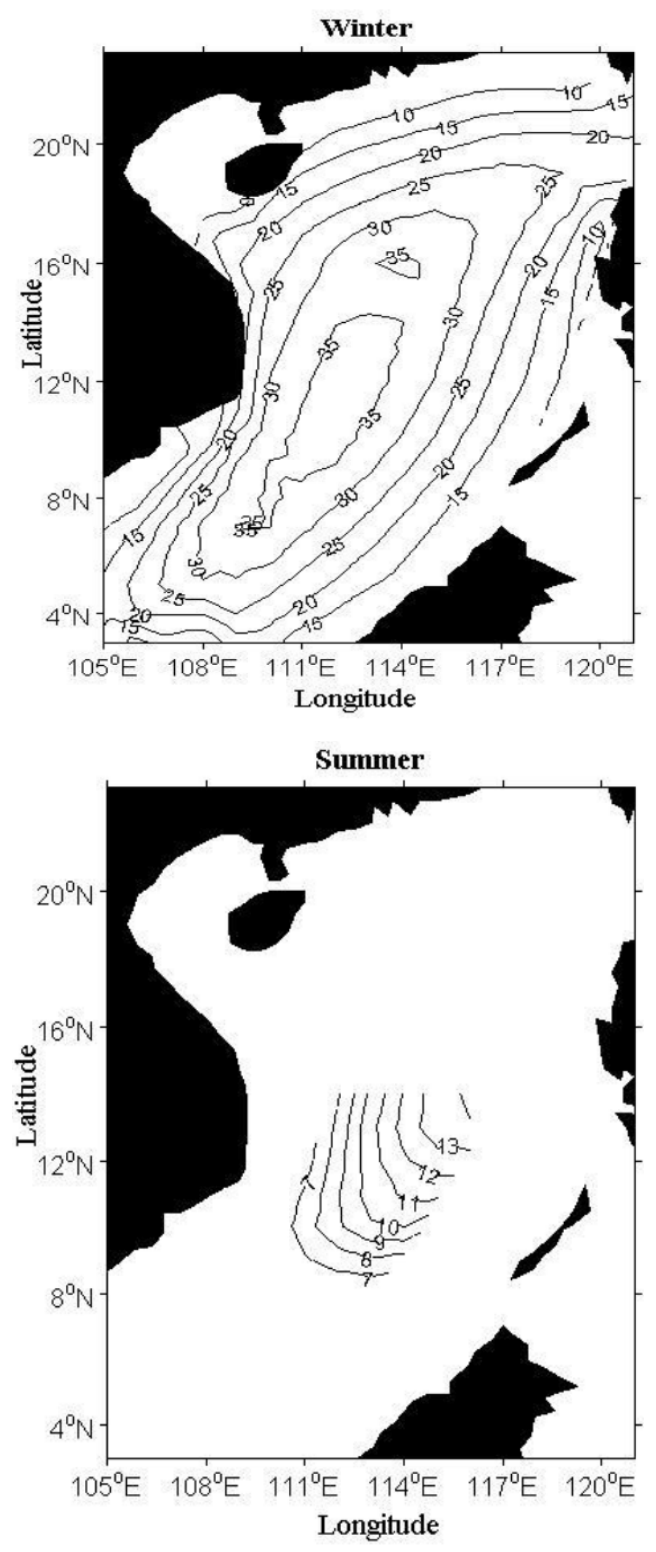
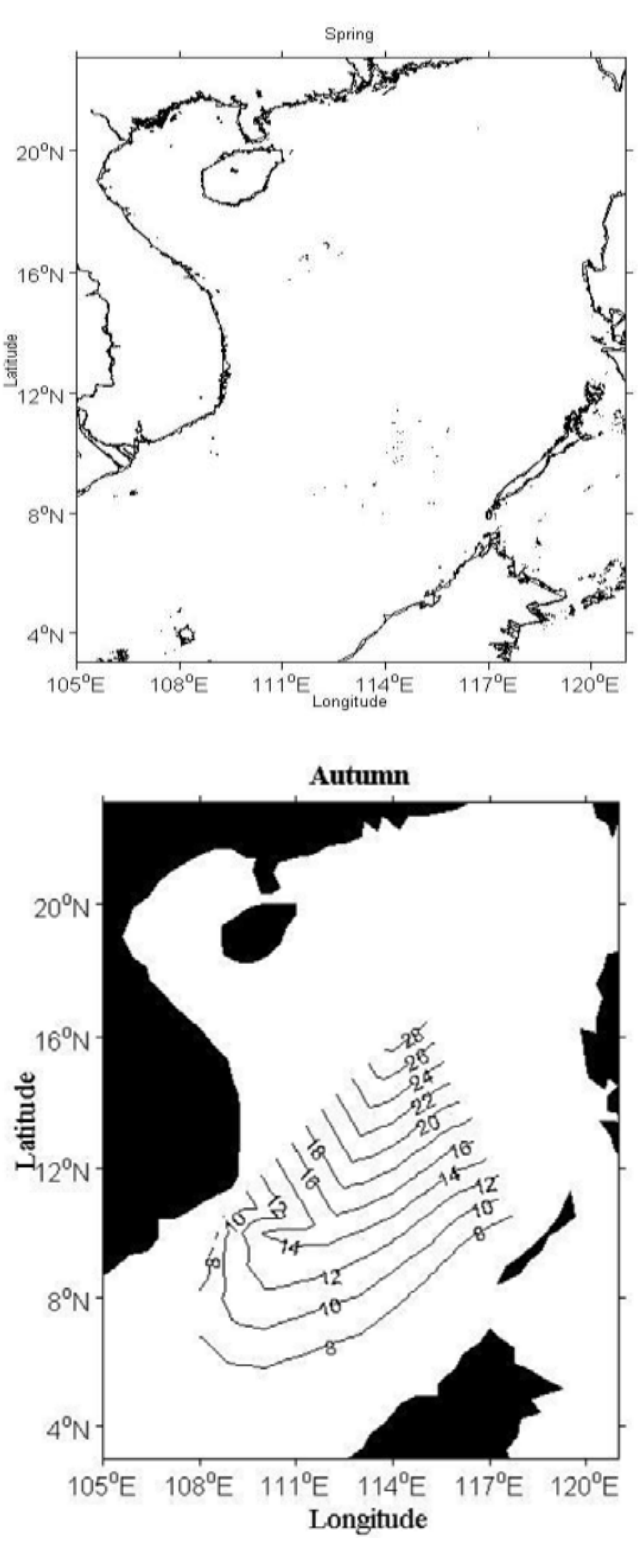

Figure 12: Wave power density in the relative rich-energy region for the seasons, unit: $\mathrm{kW} / \mathrm{m}$.

1999 , it is smallest $(14 \mathrm{~kW} / \mathrm{m})$ in year 1979. In the spring, the relative-rich energy is only available in $16 y e a r s$ out of the 30years considered in this study. It peaks at $9 \mathrm{~kW} / \mathrm{m}$ in year 1986 and least $(6.2 \mathrm{~kW} / \mathrm{m})$ in year 1988. During summer, the relative-rich energy is available in all years except in year 1998. A maximum value of $18.5 \mathrm{~kW} / \mathrm{m}$ is seen in year 2002. Minimum values of $6.9 \mathrm{~kW} / \mathrm{m}, 6.7 \mathrm{~kW} / \mathrm{m}, 6.9 \mathrm{~kW} / \mathrm{m}$ and $6.8 \mathrm{~kW} / \mathrm{m}$ are respectively found in years 1977, 1980, 1983 and 1988. In the autumn, the relative-rich energy peaks at $27 \mathrm{~kW} / \mathrm{m}$ in year 1983 and least $(8.5 \mathrm{~kW} / \mathrm{m}$ and $8.2 \mathrm{~kW} / \mathrm{m}$ ) in years 1982 and 1987.

\section{CONCLUSIONS}

This study investigates the distribution of wave power density, its stability and its relative-rich energy in the SCS. Areas of extremely large wave power density values (approximately $20-22 \mathrm{~kW} / \mathrm{m}$ ) are located around Xisha and Zhongsha in the north-central SCS. The distribution of wave power density also has seasonal differences due to the East Asian monsoon. The wave power density is sufficient in winter and autumn and insufficient in spring and summer. The wave energy is generally least abundant around Hainan, Kalimantan and Palawan, therefore, estimates of wave power density are less reliable in these regions.

Highest wave power density values of $12.7 \mathrm{~kW} / \mathrm{m}$ and $12.9 \mathrm{~kW} / \mathrm{m}$ are respectively found in years 1986 and 1999. The largest wave power density of $29 \mathrm{~kW} / \mathrm{m}$ is found during winter in year 1999. This is followed by wave power density of $16.5 \mathrm{~kW} / \mathrm{m}, 16.9 \mathrm{~kW} / \mathrm{m}$, 

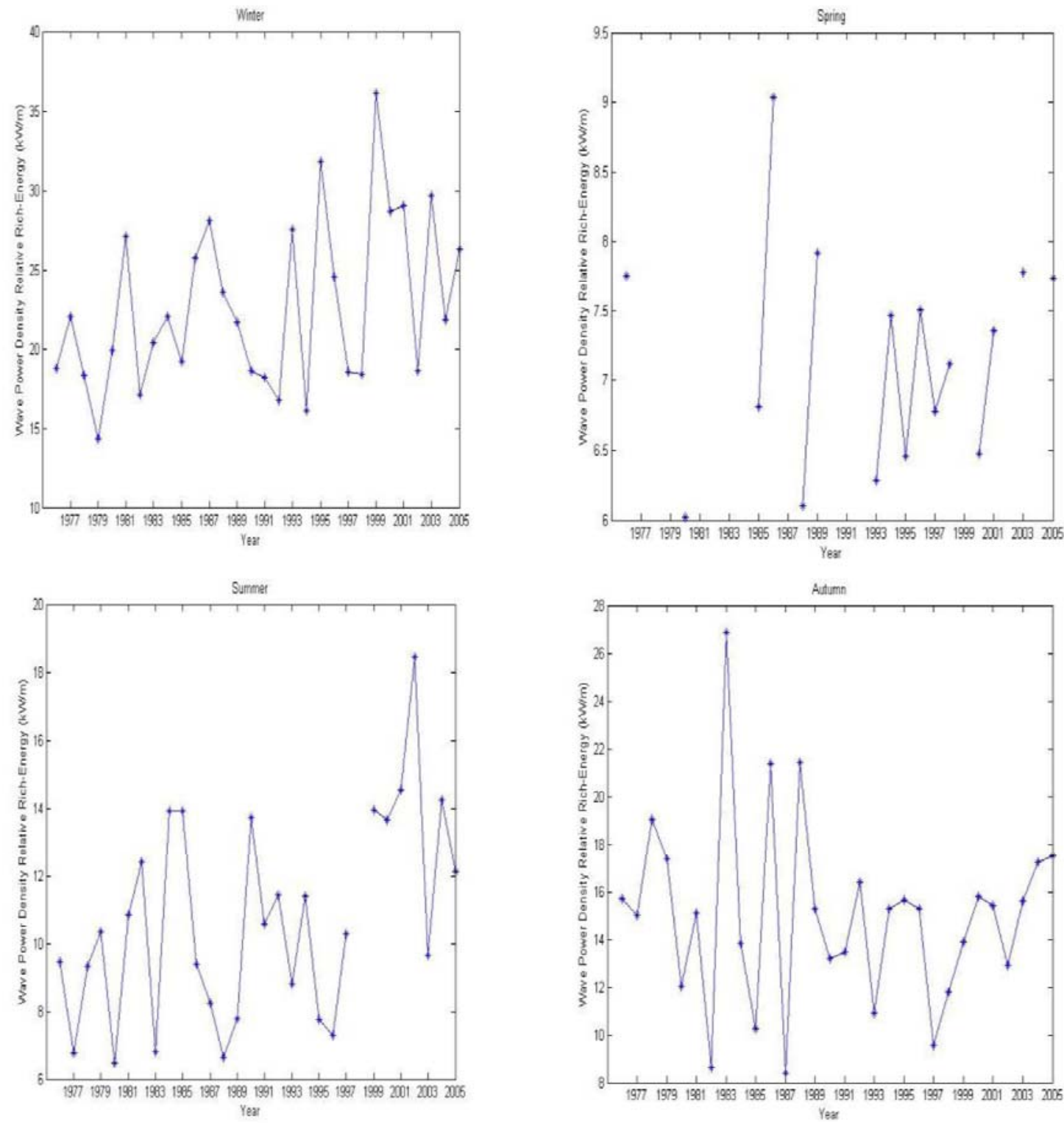

Figure 13: Wave power density relative rich-energy, unit: $\mathrm{kW} / \mathrm{m}$.

$17.2 \mathrm{~kW} / \mathrm{m}$ and $17.4 \mathrm{~kW} / \mathrm{m}$ found in autumn respectively in years 1983, 1986, 1988 and 1992 .

Wave power density stability decreases upwards (cov 1-5) in most waters in the southern to the northern SCS. The wave power density is most stable in winter and there is generally more stability in the offshore than in the near shore regions of the SCS. Wave power density is most stable in years 1976, 1997 and 2004 with stability values of $1.96,1.98$ and 1.9 respectively. The stability value of 0.9 is the greatest in 1980 during winter.

Lastly, the wave power density relative-rich energy regions occupy the largest area in the SCS during winter than in the other seasons. The relatively richest energy is generally concentrated in the central SCS and around Xisha and Zhongsha. No area is identified as a relative-rich energy region during spring in the SCS.

Winter 1999 and autumn 1983 have high relativerich energy with values of $37 \mathrm{~kW} / \mathrm{m}$ and $27 \mathrm{~kW} / \mathrm{m}$ respectively.

\section{NOMENCLATURE}

SCS = South China Sea

$\mathrm{SWH}=$ Significant wave height

RMSE $=$ Root mean square error 


$$
\begin{aligned}
& \mathrm{CC}=\text { Correlation coefficient } \\
& \mathrm{SI}=\text { Scatter index } \\
& \mathrm{COV}=\text { coefficient of variation } \\
& \text { WW3 }=\text { WAVEWATCH-III }
\end{aligned}
$$

\section{ACKNOWLEDGEMENTS}

This work is financially supported by the National Natural Science Foundation of China (51479183, 51509226), and the fundamental research funds for the central universities (201513040).

\section{REFERENCES}

[1] Chu PC, Cheng KF. South China Sea wave characteristics during Typhoon Muifa passage in winter 2004. J Oceanography 2008; 64: 1-21.

http://dx.doi.org/10.1007/s10872-008-0001-9

[2] Chu PC, Lu SH, Liu WT. Uncertainty of the South China Sea prediction using NSCAT and NCEP winds during tropical storm Ernie 1996. J Geophys Res 1999; 104: 11273-89. http://dx.doi.org/10.1029/1998JC900046

[3] Edmons NL, Fan CW. Dynamical mechanisms for the South China Sea seasonal circulation and thermohaline variabilities. J Phys Oceanogr 1999b; 29: 2971-2989. http://dx.doi.org/10.1175/15200485(1999)029<2971:DMFTSC >2.0.CO;2

[4] Veneziano JM, Fan CW. Response of the South China Sea to tropical cyclone Ernie 1996. J Geophys Res 2000; 105(13): 991-14 009.

[5] Zheng CW, Pan J. Assessment of the global ocean wind energy resource. Renewable Sustainable Energy Rev 2014; 33: 382-391.

http://dx.doi.org/10.1016/j.rser.2014.01.065

[6] Li Y, Yu YH. A synthesis of numerical methods for modeling wave energy converter-point absorbers. Renewable Sustainable Energy Rev 2012; 16(6): 4352-4364. http://dx.doi.org/10.1016/..rser.2011.11.008

[7] Falc ao AF, DO. Wave energy utilization: A review of the technologies. Renewable Sustainable Energy Rev 2010; 14(3): 899-918.

http://dx.doi.org/10.1016/j.rser.2009.11.003

[8] Iglesias G, Lopez M, Carballo R, Castro A, Fraguela JA, Frigaard P. Wave energy potential in Galicia (NW Spain). Renewable Energy 2009; 34(11): 2323. http://dx.doi.org/10.1016/j.renene.2009.03.030

[9] Iglesias G, Carballo R. Offshore and inshore wave energy assessment: Asturias (N Spain). Energy 2010; 35(5): 19641972.

http://dx.doi.org/10.1016/j.energy.2010.01.011
[10] Akpamar A, Komurcu Ml. Assessment of wave energy resource of the Black Sea based on 15-year numerical hindcast data. Appl Energy 2013; 101: 502-512. http://dx.doi.org/10.1016/j.apenergy.2012.06.005

[11] Zheng CW, Zhuang H, Li X, Li XQ. Wind energy and wave energy resources assessment in the East China Sea and South China Sea. Sci China Technol Sci 2012; 55(1): 163173.

http://dx.doi.org/10.1007/s11431-011-4646-z

Zheng CW, Zhou L, Huang CF, Shi YL, Li JX, Li J. The longterm trend of a sea surface wind speed and a (wind wave, swell, mixed wave) wave height in global ocean during the last 44 a. Acta Oceanol Sin 2013a; 32(10): 1-4. http://dx.doi.org/10.1007/s13131-013-0358-5

[13] Zhang S, Liu FY, Zhang B, Ma ZZ, Jiang B. Investigation and assessment of wave energy in coastal area of China. Ocean Technol 2012; 31(3): 79e82.

[14] Wen B, Xue YG, Zhang FR, Zhao CY. Numerical simulation of wave energy resources in the China Sea. Mar Forecasts 2013; 30(2): 36e41.

[15] Zheng CW, Pan J, Li JX. Assessing the China sea wind energy and wave energy resources from 1988 to 2009 . Ocean Eng 2013; 65: 39-48.

http://dx.doi.org/10.1016/j.oceaneng.2013.03.006

[16] Zheng CW, Zhuang $\mathrm{H}$, Li X. Wind energy and wave energy resources assessment in the East China sea and South China sea. Sci China Technol Sci 2012; 55(1): $163 e 73$.

[17] Jianli R, Yuya L, Yingjie Z, et al. The implementation for the analysis system of ocean wave resources and the application of wave energy power generation. Journal of Zhejiang University of Technology (in Chinese) 2008; 36(2): 186-191.

[18] Jianli R, Yuya L, Junjie C, et al. Research on wave power application by the information system for ocean wave resources evaluation. Renewable Energy (in Chinese) 2009; 27(3): 93-97.

[19] Tolman HL. User Manual and System Documentation of WAVEWATCH-III Version 3.14.

[20] Iglesias G, Carballo R. Choosing the site for the first wave farm in a region: A case study in the Galician Southwest (Spain). Energy 2011; 36(9): 5525-5531.

http://dx.doi.org/10.1016/j.energy.2011.07.022

[21] Cornett AM. A global wave energy resource assessment. In Proceedings of the 18th International Offshore and Polar Engineering Conference held in Canada 2008; pp. 318-326.

[22] Vosough A. Wave power. Int J Multidiscip Sci Eng 2011; 2(7): 60-63.

[23] Zheng CW, Zhou L, Jia BK, Pan JL, Li X. Wave characteristic analysis and wave energy resource evaluation in the China Sea. Journal of Renewable and Sustainable Energy 2014; 6: 043101.

http://dx.doi.org/10.1063/1.4885842 